University of Nebraska - Lincoln

DigitalCommons@University of Nebraska - Lincoln

USDA National Wildlife Research Center - Staff Publications
U.S. Department of Agriculture: Animal and Plant Health Inspection Service

$7-1-2006$

\title{
INTERSPECIES COMPARISON OF PENTOSIDINE ACCUMULATION AND ITS CORRELATION WITH AGE IN BIRDS
}

Jesse A. Fallon

West Virginia University, Morgantown, West Virginia

Robert L. Cochrane

West Virginia University, Morgantown, West Virginia

Brian Dorr

U.S. Department of Agriculture, Wildlife Services, National Wildlife Research Center, brian.s.dorr@aphis.usda.gov

Hillar Klandorf

West Virginia University, Morgantown, West Virginia

Follow this and additional works at: https://digitalcommons.unl.edu/icwdm_usdanwrc

Part of the Environmental Sciences Commons

Fallon, Jesse A.; Cochrane, Robert L.; Dorr, Brian; and Klandorf, Hillar, "INTERSPECIES COMPARISON OF PENTOSIDINE ACCUMULATION AND ITS CORRELATION WITH AGE IN BIRDS" (2006). USDA National Wildlife Research Center - Staff Publications. 419.

https://digitalcommons.unl.edu/icwdm_usdanwrc/419

This Article is brought to you for free and open access by the U.S. Department of Agriculture: Animal and Plant Health Inspection Service at DigitalCommons@University of Nebraska - Lincoln. It has been accepted for inclusion in USDA National Wildlife Research Center - Staff Publications by an authorized administrator of DigitalCommons@University of Nebraska - Lincoln. 


\title{
INTERSPECIES COMPARISON OF PENTOSIDINE ACCUMULATION AND ITS CORRELATION WITH AGE IN BIRDS
}

\author{
Jesse A. Fallon, ${ }^{1}$ Robert L. Cochrane, ${ }^{1}$ Brian Dorr, ${ }^{2}$ and Hillar Klandorf ${ }^{1,3}$ \\ ${ }^{1}$ Division of Animal and Veterinary Sciences, West Virginia University, Morgantown, West Virginia, USA; and \\ ${ }^{2}$ U.S. Department of Agriculture, Wildlife Services, National Wildlife Research Center, Mississippi Field Station, \\ P.O. Drawer 6099, Mississippi State University, Mississippi 39762, USA
}

Aвstract. - Recent studies suggest that a linear correlation exists between the age of individual birds and accumulation of the advanced glycation endproduct pentosidine (Ps). We compared Ps accumulation in skin tissue of Ruffed Grouse (Bonasa umbellus) and Double-crested Cormorants (Phalacrocorax auritus). Skin samples were taken from the breasts of 52 Ruffed Grouse of known ages ranging from a few days to 10 years. Skin was cleaned of feathers and adipose tissue, acid hydrolyzed, and measured for collagen content via hydroxyproline spectrophotometric assay. Pentosidine concentrations were determined using reverse-phase high-performance liquid chromatography. Fluorescent detection (excitation: $310 \mathrm{~nm}$, emission: $385 \mathrm{~nm}$ ) revealed that concentrations of Ps per milligram of collagen increased curvilinearly with age $\left(r^{2}=0.87, P<0.0001\right)$. Additionally, a blind study of 19 Double-crested Cormorants revealed a linear relationship between Ps concentrations and age $\left(r^{2}=\right.$ 0.93). Comparison of these two species revealed a more rapid accumulation of Ps in Ruffed Grouse. Accurate age information could aid species recovery programs and provide insights into longevity, now understood entirely from banding programs and captive birds. Received 26 August 2004, accepted 20 October 2005.

Key words: aging, Bonasa umbellus, Double-crested Cormorant, pentosidine, Phalacrocorax auritus, Ruffed Grouse.

Comparación entre Especies de la Acumulación de Pentosidina y su Correlación con la Edad de las Aves

Resumen.-Estudios recientes sugieren que existe una correlación lineal entre la edad de las aves y la acumulación de pentosidina (Ps), que es un producto de la glicólisis. Comparamos la acumulación de Ps en los tejidos de la piel de Bonasa umbellus y Phalacrocorax auritus. Se tomaron muestras de la piel del pecho de 52 individuos de B. umbellus de edades que variaban entre unos pocos días y 10 años. A la piel se le sacaron las plumas y el tejido adiposo, se hidrolizó con ácido y se midió su contenido de colágeno mediante un ensayo espectrofotométrico de hidroxiprolina. Las concentraciones de pentosidina fueron determinadas usando cromatografía líquida de alto rendimiento de fase reversa. La detección fluorescente (excitación: 310 nm, emisión: $385 \mathrm{~nm}$ ) reveló que las concentraciones de Ps por miligramo de colágeno aumentaron de manera curvilínea con la edad $\left(r^{2}=0.87, P<0.0001\right)$. Además, un estudio de 19 individuos de $P$. auritus reveló una relación lineal entre las concentraciones de Ps y la edad $\left(r^{2}=0.93\right)$. Las comparaciones entre las dos especies revelaron la existencia de una acumulación más rápida de Ps en B. umbellus. Contar con información precisa sobre la edad podría ayudar a los programas de recuperación de especies y brindar aportes al estudio de la longevidad, que hoy es entendido enteramente mediante los programas de anillado y mediante el estudio de aves cautivas.

${ }^{3}$ E-mail: hillar.klandorf@mail.wvu.edu 
The PHenomenon of aging is progressive, irreversible, and universal to all living things. One unavoidable outcome of aging is the modification of proteins by sugars, which, through a non-enzymatic process known as the Maillard reaction, can lead to the formation of crosslinked compounds termed "advanced glycation endproducts" (AGEs) (Cerami et al. 1987). These protein crosslinks, like the process of aging with which their formation is associated, are irreversible. Because of their stability, AGEs are cumulative in vivo, most noticeably in long-lived tissues such as collagen. One such AGE, pentosidine (Ps), is a stable, fluorescent crosslink comprising an arginine and lysine residue bound by a pentose sugar. The cumulative nature and inherent fluorescence of Ps make it a valuable biomarker of aging that can be measured in the laboratory.

Pentosidine has been found to accumulate with age in the skin collagen of a variety of mammalian species (Sell et al. 1996). Moreover, interspecies comparison of Ps accumulation in mammals has demonstrated that Ps accumulates at different rates in different species, and that an inverse relationship exists between maximum longevity and Ps (Sell et al. 1996). That is, species with shorter life spans tend to accumulate Ps more rapidly than those with greater maximum life expectancies.

Work by Iqbal et al. $(1997,1999)$ confirmed the accumulation of Ps with age in domestic poultry. More recently, Chaney et al. (2003) found that Ps accumulation was linearly correlated with age in a variety of wild bird species. These studies indicated that the accumulation of the glycoxidation product Ps is strongly correlated with the age of individual birds, verifying it as a biomarker for the aging process (Iqbal et al. 1999, Chaney et al. 2003, Fallon et al. 2006). Furthermore, Chaney et al. (2003) suggested that the linear accumulation of Ps could be used to estimate the chronological age of individual birds. However, this work did not investigate potential differences between species. To accurately employ Ps accumulation as a technique to estimate age, we must first determine whether interspecific differences exist.

Because most birds exhibit few or no external morphological changes beyond adulthood, current information on aging relies on banding data, a labor-intensive and protracted technique. Using Ps as a biomarker for aging would provide insight into age-related population demographics, such as the onset of sexual maturity, age-specific fecundity, and the effect of age on behavior and susceptibility to disease (Maransky and Bildstein 2001, Johnsen et al. 2003). Additionally, because many species are strong pair-bonders, species survival programs would benefit from the ability to pair nonbanded birds of similar ages.

If this technique is to be used as a chronological estimate of age in birds-and if, as in the mammalian models presented by Sell et al. (1996), Ps accumulation varies between individual species with different potential maximum life spans - we must reach a greater understanding of what differences exist among avian species with varying life expectancies. For this reason, we examined the potential use of Ps as a biomarker to estimate the chronological age of a relatively short-lived, granivorous species, the Ruffed Grouse (Bonasa umbellus; hereafter "grouse"). These data are compared with a blind study in which we examined Ps accumulation in a longer-lived, piscivorous species, Double-crested Cormorants (Phalacrocorax auritus; hereafter "cormorants").

\section{Materials and Methods}

Tissue procurement.-Grouse samples were obtained at necropsy from West Virginia University's captive colony immediately after death. Approximately $25 \mathrm{~g}$ of skin were removed from the breasts of 29 male and 23 female grouse of known ages ranging from 33 days to 10 years. For up to one month before processing, samples were stored at $-80^{\circ} \mathrm{C}$.

Previously banded cormorants of known ages were collected from October through April of 2002-2003 and 2003-2004 in Mississippi and Alabama by employees of the National Wildlife Research Center (U.S. Department of Agriculture, Wildlife Services). Banded cormorants were also obtained from individuals and agencies taking cormorants under the U.S. Fish and Wildlife Service unlimited depredation order. Skin samples $(n=19)$ of $\sim 150 \mathrm{~g}$ were taken at necropsy and frozen in a sterile saline solution until assayed. Age data were not provided with the samples, which were processed upon arrival.

Sample processing.-Skin samples of $\sim 2 \mathrm{~cm}^{2}$ were prepared as described by Iqbal et al. (1997) and Chaney et al. (2003). Samples were scraped and cleaned of feather shafts, adipose tissue, and circulatory vessels. Forty milligrams of the remaining connective tissue were minced and delipidated in a 2:1 chloroform:methanol solution 
for $18 \mathrm{~h}$. Following delipidation, the residue was recovered by centrifugation and placed in $4 \mathrm{~mL}$ of 1:1 water:methanol solution for $2 \mathrm{~h}$. Again the residue was recovered by centrifugation, and then acid hydrolyzed in $4 \mathrm{~mL}$ of de-aerated $6 \mathrm{~N} \mathrm{HCL}$ for $18 \mathrm{~h}$. The acid was evaporated by a Speed-Vac (Savant Instruments, Farmingdale, New York), and then the residue was reconstituted with $500 \mu \mathrm{L}$ of water. Each sample was then filtered through a Costar Spin- $X$ centrifuge tube filter.

Collagen and pentosidine measurement.Collagen content was determined via spectrophotometric hydroxyproline assay, assuming $14 \%$ of collagen by weight to be hydroxyproline (Maekawa et al. 1970).

Measurement of Ps concentration was accomplished via slight modification of techniques used by Iqbal et al. (1999) and Chaney et al. (2003). Pentosidine concentrations were estimated using a Waters 2690 high-performance liquid chromatography work station with a Waters 494 in-line fluorescence detector (excitation: $310 \mathrm{~nm}$, emission: $385 \mathrm{~nm}$ ). Elutions off the C-18 column (YMC OCS-AQ $4.6 \times$ $250 \mathrm{~mm}$ ) were obtained using a linear gradient of $5-28 \%$ acetonitrile in water with $0.01 \mathrm{M}$ heptafluorobutyric acid from 0 to $35 \mathrm{~min}$. The column was cleaned and equilibrated for 18 and $12 \mathrm{~min}$, respectively. Pentosidine concentrations were measured in duplicate samples spiked with known amounts of Ps to ensure accurate elution time. Quantification of Ps concentration was accomplished using a Ps standard. Peaks were integrated using MILLENNIUM 32, version 3.05.01 (Waters, Milford, Massachusetts).

Statistical analysis.-Regression analysis and comparison were completed using SAS software (SAS Institute, Cary, North Carolina). Grouse and cormorant data were analyzed separately using Proc GLM to determine the relationship between age and Ps (pmol per milligram of collagen) for each species. A $t$-test was performed to compare the two slopes generated by the linear regression analyses.

\section{Results}

Concentration of Ps increased with age in both species of birds.

Ruffed Grouse.-Regression analysis of 52 grouse skin samples revealed a curvilinear increase of Ps in grouse with $y=0.0059 x^{2}+$ $0.1551 x+11.636, r^{2}=0.87(P<0.0001)$ (Fig. 1).
Grouse data were also fitted with the linear regression line $y=0.8063 x+2.1542, r^{2}=0.80(t=$ $15.20, P<0.0001)$. For further analytical comparisons, the simple linear regression equation (having only a modest effect on the coefficient) will be considered for ease of interspecies comparison. No significant sex differences were detected using either analysis.

Double-crested Cormorants. - Pentosidine data from the blind study of 19 cormorants were used to group birds into two distinct age classes. Each of these predictions was independently found to be accurate on the basis of age data provided to our laboratory by the U.S. Geological Survey Bird Banding laboratory.

Pentosidine concentrations increased linearly with age in the cormorants, with $y=0.1914 x+$ 6.6701, $r^{2}=0.93$ ( $t=15.40, P<0.0001$; Fig. 2$)$.

Interspecies comparison. - Comparison between species revealed a more rapid increase in Ps concentrations in grouse than in the longerlived cormorants (Fig. 3). Slope analysis of the regressions confirmed a significant difference in Ps concentrations ( $t=11.03, P<0.0001)$. Additionally, comparison of the regression line

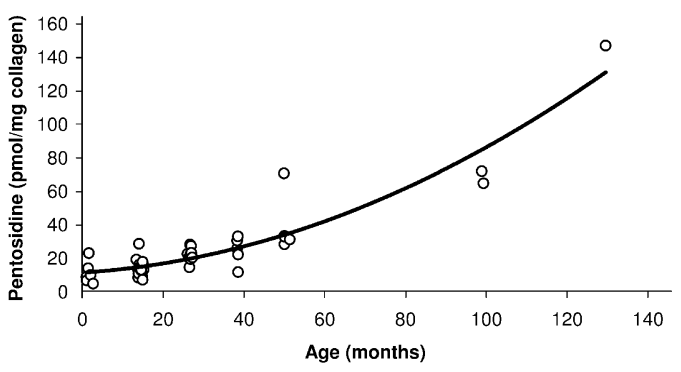

FIG. 1. Pentosidine concentration as a function of age in Ruffed Grouse.

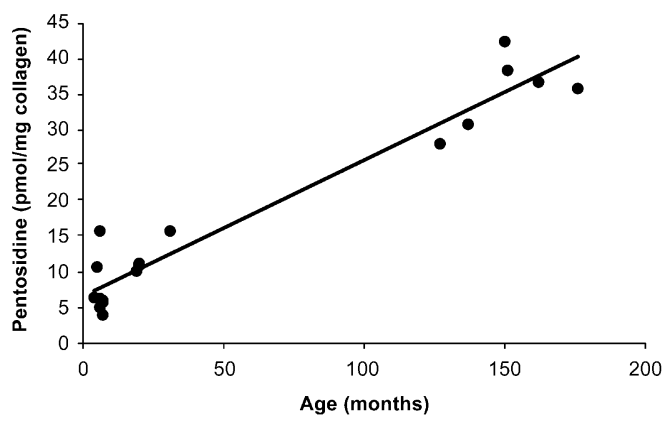

FIG. 2. Pentosidine concentration as a function of age in Double-crested Cormorants. 


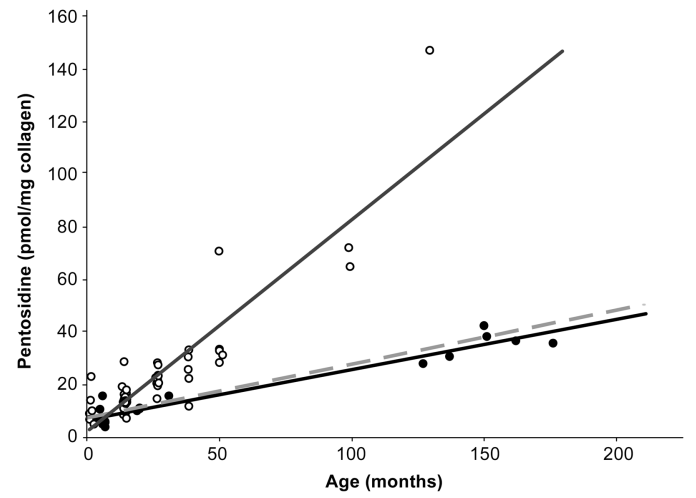

FIg. 3. Pentosidine concentration as a function of age in Ruffed Grouse (open circles) and Double-crested Cormorants (filled circles). Dotted line represents results from Cheney et al. (2003).

from Chaney et al. (2003) revealed a slope very similar to the cormorant data, and different from the grouse data (Fig. 3).

\section{Discussion}

In agreement with previous studies in birds, Ps accumulation increased with age in both Ruffed Grouse and Double-crested Cormorants. The goal of this work is to measure concentrations of skin Ps and, using these established relationships, infer unknown ages of individual birds. Data from the blind study of cormorants, which led to an accurate prediction of the oldest, youngest, and similarly aged birds, demonstrate the power of this technique. However, the results of the present study suggest that Ps calibration should be confirmed for each species.

Although a curvilinear relationship provided the best fit for the grouse data, this relationship incorporated the Ps measurement of a particularly aged, captive-reared grouse that was likely approaching 10 years of age, the maximum theoretical life span of this species. More data from grouse of similar age may help confirm this curvilinear relationship. It is suggested that as individuals reach extreme old age, the formation of AGEs such as Ps accelerate dramatically because of impaired collagen turnover or an increase in oxidative damage leading to agerelated physiological malfunctions, such as end-stage renal disease, as has been suggested in humans (Sell and Monnier 1990).
Although a curvilinear relationship between age and Ps concentration was not supported by the cormorant data (Fig. 2), the lack of individuals of intermediate ages may have affected slope estimates for this species. Additional data from "middle-aged" cormorants may indicate a curvilinear relationship more similar to that of the grouse, though the less rapid accumulation of Ps in this longer-lived species would remain.

The distinct difference between Ps accumulation in grouse and in cormorants, as illustrated in Figure 3, could be attributed to several factors. It may be linked to species-specific skin biology, such as collagen turnover, as suggested by Sell et al. (1996). It is possible that cormorants simply inherit a more efficient system to replace cross-linked skin collagen, which leads to the comparably reduced rate of Ps accumulation demonstrated here.

One factor that contributes to formation of Ps, and thereby may contribute to its rate of accumulation, is glycemia. Human diabetics have been shown to have a more rapid accumulation of Ps than their nondiabetic counterparts, which suggests that an inability to maintain appropriate levels of blood sugar can lead to an increase in the rate of AGE formation (Sell and Monnier 1990). However, studies suggest that glycemia and glycoxidation rates are not strictly linked (Sell et al. 1996). Birds are known to maintain higher levels of blood glucose concentrations than mammals of similar size (Holmes et al. 2001), yet not only do birds tend to live much longer, they also appear to accumulate Ps at similar or reduced rates (Iqbal et al. 1999). This suggests that the relationship between blood sugar concentration and glycoxidation products is not concrete-that some control mechanism must exist. Nonetheless, the contribution of circulating glucose should be explored further.

Another possible explanation for this difference is that the grouse in the present study were raised in captivity and fed ad-libitum, whereas the cormorant specimens had to rely on their foraging abilities in the wild. In mice and poultry, it has been demonstrated that dietary restriction leads to a decrease in accumulation of Ps, as well as to an increase in longevity (Iqbal et al. 1999, Sell et al. 2000). The difficulty in finding food in the wild, compared with the unlimited access in a captive setting, may represent a situation of comparative dietary restriction. On the other hand, an animal foraging 
for food in the wild is likely to require higher energy expenditures, which will lead to an increase in metabolic demand and oxidative damage, potentially increasing the rate of Ps accumulation (Yu et al. 1991). An investigation into the differences in Ps accumulation between captive and free-ranging populations within an individual species may provide clarification.

It seems more likely, however, that the difference in rates of Ps accumulation is tied to overall longevity of the individual species, as suggested in mammals (Sell et al. 1996). Grouse are rather short-lived birds; the oldest wild Ruffed Grouse on record reached 8.5 years of age (Klimkiewicz and Futcher 1989). Double-crested Cormorants, on the other hand, may live much longer; one wild individual reached nearly 18 years of age (Klimkiewicz and Futcher 1989). Although the underlying mechanisms of the association between Ps accumulation and longevity remain to be established, an inverse relationship between the two has been demonstrated in a variety of mammalian species (Sell et al. 1996). Similarly, recent work suggests that a correlation between the rate of telemetric shortening, another senescence indicator, and the age of birds appears to be linked to species longevity (Haussmann et al. 2003, Vleck et al. 2003).

One potential contributor to the difference in both longevity and rate of Ps accumulation between grouse and cormorants may be speciesspecific metabolic rates. A general inverse correlation between metabolic rate and maximum life expectancy has been established (Speakman et al. 2002). Moreover, recent evidence suggests that energy metabolism is a major determinant of endogenous oxidative stress (resulting from the body's production of reactive oxygen species) as well as life span (Mattson 2002). It is possible that the smaller, more metabolically active grouse have a higher respiratory quotient and more rapid oxygen consumption, which lead to an increase in free-radical-mediated damage. This may contribute to an increase in glycoxidation rate (i.e., more rapid Ps accumulation), as well as an increase in nonspecific cellular damage, ultimately resulting in reduced longevity.

Antioxidants are compounds that can combat oxidative stress by quenching free radicals (Clarkson and Thompson 2000). It has been suggested that the remarkable longevity of individuals in the class Aves is linked to their production of the endogenous antioxidant uric acid (Klandorf et al. 1999, Simoyi et al. 2002, Stinefelt et al. 2005). Perhaps, then, cormorants are able to retard the formation of Ps and prevent some oxidative damage by maintaining more efficient antioxidant systems, which include higher concentrations of uric acid, than grouse. For example, high-protein diets in poultry are known to increase concentrations of uric acid, which can be linked to a reduction in leukocyte oxidative activity (Machin et al. 2004). We are currently investigating the role of uric acid in longevity and protein crosslinking.

If grouse generate more reactive oxygen species or maintain lower levels of endogenous antioxidants than cormorants, it would contribute to both their more rapid biological aging (i.e., shorter maximum life expectancies) and to their more rapid accumulation of the AGE Ps. Further study into these possibilities may not only improve our understanding of the differences in rate of Ps accumulation, but also contribute to our understanding of the aging process in general.

Whether skin biology, glycemic index, dietary restriction, composition of diet, metabolic rate, oxidative stress, or a combination of these factors contributes to the differences in Ps accumulation demonstrated here, it seems unlikely that a generic relationship between the age of individual birds and Ps accumulation will be applicable to all species. However, the similarity between the relationship found for the variety of species studied by Chaney et al. (2003) and for the cormorants in the present study suggests that some overlap may exist (Fig. 3). Perhaps Ps accumulation between closely related species or species with similar life spans will coincide enough to make some generalizations possible. Further investigation into family-, genus-, and species-specific models are needed to confirm this.

Although these data present some variation in age estimates, they also reveal a strong correlation between Ps accumulation and age within individual species, which suggests that this technique may develop into a useful tool for age estimation. As we continue to refine the technique, examine the differences between individual species, and reduce the size of skin samples necessary for analysis, we will be able to make more precise estimates of the ages of birds. 


\section{Acknowledgments}

We sincerely acknowledge E. Falkenstein of West Virginia University for laboratory assistance, V. M. Monnier of Case Western University (Cleveland, Ohio) for providing Ps standard, G. Seidel of West Virginia University for statistical support, and U.S. Department of Agriculture Wildlife Services staff in Mississippi for collection of Double-crested Cormorants. This is scientific article no. 2935, published with the approval of the West Virginia University Agricultural and Forestry Experiment Station.

\section{Literature Cited}

Cerami, A., H. Vlassara, and M. Brownlee. 1987. Glucose and aging. Scientific American 256:90-96.

Chaney, R. C., Jr., K. P. Blemings, J. Bonner, and H. Klandorf. 2003. Pentosidine as a measure of chronological age in wild birds. Auk 120:394-399.

Clarkson, P. M., and H. S. Thompson. 2000. Antioxidants: What role do they play in physical activity and health? American Journal of Clinical Nutrition 72:637S-646S.

FAllon, J. A., W. J. RAdKe, and H. Klandorf. 2006. Stability of pentosidine concentrations in museum study skins. Auk 123:148-152.

Haussmann, M. F., D. W. Winkler, K. M. O’Reilly, C. E. Huntington, I. C. T. Nisbet, AND C. M. VLECK. 2003. Telomeres shorten more slowly in long-lived birds and mammals than in short-lived ones. Proceedings of the Royal Society of London, Series B 270: 1387-1392.

Holmes, D. J., R. Fluckiger, and S. N. Austad. 2001. Comparative biology of aging in birds: An update. Experimental Gerontology 36: 869-883.

Iqbal, M., I. L. Probert, N. H. Alhumadi, and H. Klandorf. 1999. Protein glycosylation and advanced glycosylation endproducts (AGEs) accumulation: An avian solution? Journals of Gerontology, Series A 54:B171-B176.

Iqbal, M., I. L. Probert, and H. Klandorf. 1997. Effect of dietary aminoguanidine on tissue pentosidine and reproductive performance in broiler breeder hens. Poultry Science 76: 1574-1579.

Johnsen, A., J. T. Lifjeld, and C. Krokene. 2003. Age-related variation in mate-guarding intensity in the Bluethroat (Luscinia s. svecica). Ethology 109:147-158.

Klandorf, H., I. L. Probert, and M. Iqbal. 1999. In defense against hyperglycemia: An avian strategy. World Poultry Science 55:1-17.

Klimkiewicz, M. K., and A. G. Futcher. 1989. Longevity records of North American birds: Supplement 1. Journal of Field Ornithology 60:469-494.

Machin, M., M. F. Simoyi, K. P. Blemings, AND H. Klandorf. 2004. Increased dietary protein elevates plasma uric acid and is associated with decreased oxidative stress in rapidly-growing broilers. Comparative Biochemistry and Physiology B, Biochemical Molecular Biology 137:383-390.

Maekawa, T., T. K. Rathinasamy, K. I. Altman, AND W. F. Forbes. 1970. Changes in collagen with age. I. The extraction of acid soluble collagens from the skin of mice. Experimental Gerontology 5:177-186.

Maransky, B. P., and K. L. Bildstein. 2001. Follow your elders: Age-related differences in the migration behavior of Broad-winged Hawks at Hawk Mountain Sanctuary, Pennsylvania. Wilson Bulletin 113:350-353.

Mattson, M. P. 2002. Brain evolution and life span regulation: Conservation of signal transduction pathways that regulate energy metabolism. Mechanisms of Ageing and Development 123:947-953.

Sell, D. R., N. R. Kleinman, and V. M. Monnier. 2000. Longitudinal determination of skin collagen glycation and glycoxidation rates predicts early death in C57BL/6NNIA mice. The FASEB Journal 14:145-156.

Sell, D. R., M. A. Lane, W. A. Johnson, E. J. Masoro, O. B. Mock, K. M. Reiser, J. F. Fogarty, R. G. Cutler, D. K. Ingram, G. S. Roth, And V. M. Monnier. 1996. Longevity and the genetic determination of collagen glycoxidation kinetics in mammalian senescence. Proceedings of the National Academy of Sciences USA 93:485-490.

Sell, D. R., And V. M. Monnier. 1990. End-stage renal disease and diabetes catalyze the formation of a pentose-derived crosslink from aging human collagen. Journal of Clinical Investigation 85:380-384.

Simoyi, M. F., K. VAn Dyke, and H. Klandorf. 2002. Manipulation of plasma uric acid in broiler chicks and its effect on leukocyte oxidative activity. American Journal of 
Physiology: Regulatory, Integrative, and Comparative Physiology 282:R791-R796.

Speakman, J. R., C. Selman, J. S. McLaren, and E. J. HARper. 2002. Living fast, dying when? The link between aging and energetics. Journal of Nutrition 132:1583S-1597S.

Stinefelt, B., S. S. Leonard, K. P. Blemings, X. ShI, AND H. Klandorf. 2005. Free radical scavenging, DNA protection, and inhibition of lipid peroxidation mediated by uric acid. Annals of Clinical and Laboratory Science 35:37-45.
Vleck, C. M., M. F. Haussmann, and D. Vleck. 2003. The natural history of telomeres: Tools for aging animals and exploring the aging process. Experimental Gerontology 38: 791-795.

Yu, B. P., D. W. Lee, and J. H. Chio. 1991. Pages 191-197 in Biological Effects of Dietary Restriction (L. Fishbein, Ed.). SpringerVerlag, New York.

Associate Editor: R. C. Fleischer 